\title{
Improving Early Warning System Indicators for Crisis Manifestations in the Russian Economy
}

\author{
Alexander Semin ${ }^{1, *}$, Marina Vasiljeva ${ }^{2}$, Alexander Sokolov ${ }^{3}$, Nikolay Kuznetsov ${ }^{4}$, \\ Maksim Maramygin ${ }^{5}$, Maria Volkova ${ }^{6}$, Angelina Zekiy ${ }^{7}$, Izabella Elyakova ${ }^{8}$ and \\ Natalya Nikitina ${ }^{9}$
}

1 Department of Strategic and Industrial Management, Ural State Mining University, Yekaterinburg, 620144 Sverdlovsk Oblast, Russia

2 Top Management, Atlantic Science and Technology Academic Press, Boston, MA 01233, USA; marina.vasiljeva2017@gmail.com

3 Department of Economics Theory, MIREA-Russian Technological University, 119454 Moscow, Russia; sokolov_a_researcher@yahoo.com

4 Institute of Economic Policy and Economic Security, Financial University under the Government of the Russian Federation, 125993 Moscow, Russia; nikolay.kuznetsov53@gmail.com

5 Department of Finance, Monetary Circulation and Credit, Ural State University of Economics, Yekaterinburg, 620144 Sverdlovsk Oblast, Russia; maksimmaramygin@yandex.ru

6 Department of Industrial Logistics, Bauman Moscow State Technical University, 105005 Moscow, Russia; mar1e.volkova@yandex.ru

7 Prosthodontics Department, I.M. Sechenov First Moscow State Medical University (Sechenov University), 119146 Moscow, Russia; angelinazekiy@yandex.ru

8 Department of Economics and Finance, North-Eastern Federal University, Yakutsk, 677007 Sakha Republic, Russia; izabella.elyakova@yandex.ru

9 Department of Financial Management and Financial Law, Moscow Metropolitan Governance Yury Luzhkov University, 107045 Moscow, Russia; n.nikitina_info@yahoo.com

* Correspondence: alexandrossemin@yandex.ru

Received: 3 November 2020; Accepted: 26 November 2020; Published: 30 November 2020

\begin{abstract}
The study is aimed at determining the oscillators of crisis manifestations when the Russian economy tries to make transition to the path for accelerating technological development and forming an innovative economy. Short-term cycles were determined in the development of the Russian economy from 1995 to the first half of 2020 through the Fourier spectral analysis. Using the Granger test, causal relationships between the leading indicators of the economic crisis and the real GDP index in Russia were identified and substantiated. They reflect the influence of the key rate dynamics on the volume of lending, savings, investments, the yield on securities and the exchange rate; volumes of bank loans per the share of non-performing and bad loans and innovative development of the economy. Based on the constructed neural models of the oscillator influence on the level of real GDP in Russia, it was determined that the rapid growth of bank and mortgage lending, the devaluation of the ruble, a decreased volume of gross foreign investment and the level of innovative development predetermine crisis manifestations in the national economy. The lags of the influence of changes in the leading indicators of the economic crisis on the development of the economy were calculated. The results obtained can contribute to the effectiveness of the anti-crisis regulation strategy in Russia. They can serve as a basis for increasing the efficiency of long-term innovative development and creating appropriate conditions for increasing the scientific and technological potential of the country.
\end{abstract}

Keywords: Russia; economic crisis; economy; monitoring; early warning indicators; innovation; investment 


\section{Introduction}

In the current situation, the fact of the cyclical development of national economies, conditioned by the continuous innovation and investment activities, seems to be indisputable [1,2]. In connection with the emergence of e-commerce, which contributed to the increased number of transactions and the speculative growth of the economy, the frequency of crises is rising almost exponentially [3]. Significant negative changes or deceleration in the development of parameters of economic and social dynamics are considered the signs of the crisis $[4,5]$. The economic losses caused by crises have serious social, political and economic consequences. This is especially fraught with consequences for emerging market countries characterized by low and middle incomes, unstable labor markets and weak social welfare systems $[2,6]$. For example, during the Great Depression, almost a hundred years ago, only developed countries lost $16 \%$ of their national product and the total global GDP fell by about $10 \%$ [7]. During the financial crisis of 2007-2009, GDP declined by $4.3 \%$ and the unemployment rate approached $10 \%$ [8]. The International Monetary Fund (IMF) considers any growth rate below 2.5\% to be a global recession because, in 90 percent of the time, global growth exceeds that rate [9]. According to the forecasts of leading experts, the COVID-19 pandemic will deprive the world economy of $\$ 5.5$ trillion in the next two years. World trade will decline by $13-32 \%$ in 2020 [10]. Since the COVID-19 pandemic disrupts normal economic activities and life around the world, even with an unprecedented level of monetary and fiscal stimulus, the level of the global GDP is unlikely to return to its pre-crisis trend until at least $2022[11,12]$. The Russian economy was not immune to this either. Over the next few years starting with 2020, GDP growth is expected to average about 1.5 percent [13], which is low, considering Russia's level of economic development lowering by almost $3 \%$ annually over the past three years [14].

However, Russia's economic slowdown is not new. It became apparent in 2013 when energy prices were at an all-time high. In the short run, the double shock of steep drop in oil prices and economic sanctions sent Russia into a severe recession [15]. Since 2020, the Russian economy has been heading toward recession under the influence of a whole system of destructive factors. Under the baseline scenario, Russia's GDP is projected to contract by $6 \%$ in 2020 and to become the largest decline within the last eleven years [16].

A succession of economic crises in recent decades and the threat of a recession in the global economy as a result of the COVID-19 pandemic spread has led the global and Russian academic circles to an acute urgency to improve the diagnostic tools for fluctuations in the economic trajectory [17]. Under these circumstances, many scholars focus on the early warning indicators for crisis manifestations (oscillators), which allow signaling alarming signs before the start of an exacerbation in the economic development disproportions [2,6]. Leading indicators and composite leading indexes become more significant in the context of the economic crisis. If the economic policy measures do not correspond to the real situation, the cyclical recession can significantly increase. Therefore, the recovery of the economy can be delayed. In terms of the current global crisis, composite leading indexes turned out to be effective tools for forecasting the phases of the economic cycle [2,6]. Thus, this tool is in demand and its role in economic decision-making has increased significantly. Monitoring and market centers began to appear around the world $[10,13,16-18]$. Their key task is to conduct short-term macroeconomic forecasts in order to remove uncertainty and to develop benchmarks for business and government and to determine a system of leading indicators of the economic crisis.

Currently, the process of forming complex systems for monitoring the financial market and early detection of crisis phenomena is just beginning. But it should be noted that as a result of the 1997-1999 Asian financial crisis and its chain reaction of spreading crisis phenomena to the economies of other countries, most economists singled out primarily the financial market indicators as an early warning system [2,4,19-23]. As a rule, these are the level of international reserves [2,21,23], quotation of securities [20], national currency devaluation [21], the state budget balance [19], the level of public debt [19] and so forth. The main problem of this methodology is to delimit and justify the boundaries and conditions that determine the critical value of the oscillators. Most publications were devoted to the definition of indicators and critical values for advanced economies $[4,22]$ or Asian 
countries [23,24]; the greater part of which are characterized by the vulnerability of the financial and corporate sectors [23,24], low level of international reserves and liquidity [23], low international positions of countries [24] and so forth. Such differentiation of countries significantly complicates the development of a unified and universal system of early warning indicators for all types of crises and countries with different levels of economic development. In addition, the composition of "active" factors, which actually predetermine the growth of production, changes depending on the level of the country's economic development.

The dependence on natural resources is an essential feature of the Russian economy $[25,26]$, which operates in the conditions of severe international economic sanctions [27] and a steady decline in production [14]. These factors, in turn, provoked a new non-cyclical premature crisis in the economy since 2013 [28]. The trajectory of the 2013-2016 Russian crisis differs from the world dynamics, including the economies of the USA and the EU countries, which in current conditions are in the initial period of the recovery phase [28]. Many scholars explain this peculiarity of crisis manifestation by the fact that it was caused by the unfinished wave of the transformational crisis of the Russian economy in the 1990s [28]. Consequently, today Russia's sectoral and innovation-technical potential is characterized by an insufficient level of development, which exerts a negative impact on the economy. This, in turn, determines its dependence on the level of oil prices, international sanctions and global shocks [25-27]. These aspects should also be taken into account in the early diagnosis of crises. It should also be noted that Russia as a country with an emerging market is also prone to cyclical-wave economic development due to the low level of innovation susceptibility of economic agents [29]. And given that the country's industrial development potential continues to decline, the imperfection of the process of technological modernization and the lack of a developed system of open innovation [29] should be considered as basic elements of strategic risks and should also be accounted for in the early warning systems for crisis manifestations in the economy. Economic crises in Russia most negatively affect the Russian economy, the welfare of the population and the social sphere; therefore, the timely identification of crisis signs will serve as a basis for an effective anti-crisis policy of the state. That is why, within the framework of this study, the level and features of the Russian economy development were taken into account when determining the early warning indicators of crisis manifestations. The key tasks of the scientific research: to determine the nature of the dynamics in the development of the Russian economy using spectral analysis and to substantiate the system of significant indicators according to the Granger causality test with a probability of at least $5 \%$, the change in which most significantly affects the country's GDP were the key tasks of this scientific research.

\section{Literature Review}

Currently, the works within the framework of the theory of the real business cycle are based on the concept of the dynamic stochastic general equilibrium and represent market-clearing trajectories of economic development $[30,31]$. The general balance in the modeled economy is achieved by means of the adequate response of the representative economic agents to the prevailing conditions, taking into account all their possible expectations [30]. Thus, the general equilibrium in real-cycle models is stochastic and the actual dynamics of the economic development is determined by casual shocks. In other words, according to neoclassicists, the cycle is the result of casual shocks. They are unpredictable by definition. It means that a crisis cannot be predicted with a certain chain of events [32]. The foundation for the development of the Theory of Real Business Cycles is given in Reference [33]. It has neoclassical basis, which has prevailed in the Western economy up to the present time. The first work on the Theory of Real Business Cycles was published by Kydland and E. Prescott [34]. Their theory was recognized by the international scientific community after they had received the Nobel Prize in economics in 2004 [35]. The main idea of the approach to the analysis of economic cycles presented in Reference [35] is that if the trajectories are equilibrium, the changes in the basic macro indicators are stochastic. Thus, abandoning the idea of the predecessors that the cycle is consistent deviations from a certain trajectory, they began to study not the macroeconomic series but their dispersion. 
At the beginning of the 20th century a new concept was developed, namely, the Credit and Monetary Theory of Cycles, which explained crises as a breakdown of monetary turnover. This concept is the most fully presented in Reference [36]. It was proved that the crisis is caused by credit and monetary factors and credit and the monetary policy of banks is significant. Hawtrey [36] accuses banks of limiting credits that consecutively leads to business activity reduction and causes economic crises. It should be noted that a number of scientists supports the idea of the primacy of the financial crisis as an economic crisis factor. The studies conducted in the period from 1973 to 1997 have shown that in $70 \%$ of cases the banking or currency crisis was followed by an economic crisis. If a currency and banking crisis happen simultaneously (twin crisis), then the economic crisis will be apparent. This fact is supported by the research conducted by Roberto Cardarelli, Selim Elekdag and Subir Lall—in 58 of 113 financial crisis episodes that occurred from 1980 to 2007, there was a subsequent slowdown in economic growth or a recession [6].

According to scientific literature, economic crises are almost always preceded by periods of economic fluctuations [37]. In this regard, in the 21st century, a scientific search for the "pre-crisis" diagnostics of the state of the economy becomes relevant for possible mitigation of the imbalance in economic processes and its consequences for the socio-economic system. The majority of scholars use predominantly the econometric approach and the nonparametric estimation method when developing a system of oscillators. The econometric approach consists in the development of regression models in which certain indicators of crisis phenomena act as independent variables and indicators of crisis manifestations (its probabilistic estimates) act as dependent variables [38]. The second approach is based on the use of a "signal," which makes it possible to determine the most significant financial market indicators that can actually signal the onset of financial distress using a certain system of these indicators [2,39]. In the future, the identified crisis indicators are analyzed for deviations from their determined critical values [2] and, expert estimates are employed to determine the probability of a crisis. That is, when identifying crisis indicators by the "signal" method, we can say that an individual approach is used since each prognostic variable is analyzed. The advantages of the econometric approach include the assessment of the cumulative impact of all the analyzed indicators and the ability to predict the likelihood of a crisis in the future [38].

Constructing an integral indicator that enables to predict periods of financial instability is one of the most urgent tasks of researching financial crises. The emergence of this task was actively promoted by the global financial crisis of 2008, which provoked the emergence of a large number of integral "crisis" indicators. Currently, the process of forming complex systems for monitoring the financial market and early warning of crisis phenomena gets started, the first approaches to the formation of such systems have been implemented by some international financial organizations: the IMF [40], the World Bank [13], IOSCO (International Association of Securities Commissions) [18], the Bank for International Settlements (BIS) [41], the Financial Stability Board (FSB) under the G20 [42].

Russia also has some experience in developing a system of early warning indicators for crises in the economic system: there is the Center for Macroeconomic Analysis and Short-Term Forecasting that monthly compiles a summary on composite leading indicators [43]; Analytical Credit Rating Agency (ACRA) that publishes the Financial Stress Index for Russia on a daily basis and others [44]. In addition, several individual studies are dealing with attempts to construct diagnostic indicators for integrated assessment models $[21,25,28,45]$.

To assess Russia's financial stability in 2001-2011, a system of four financial indicators was proposed enabling prediction of the values of financial stability indices for a period of six months and a year [46].

It should be noted that the above methodological approaches to the crisis early warning were mainly based on the financial market indicators as precursors to the economic imbalance and they were assessed by determining the quantitative values of their critical levels [2,4,19-23]. However, as already noted in the study, countries differ in the level of economic development; this difference determines the differentiation of active indicators of the economy at different stages of its development and the typical historical and current peculiarities of its operation. These factors necessitate the use of 
a predominantly individual approach within the framework of the early warning methodology and provide a clear understanding that financial conditions during the crisis have become tougher and unprecedented and exceptional policies are required to support their economies. Therefore, this study intends to take into consideration these responsibilities, as well as the fact that nowadays innovation is one of the most significant indicators of crisis manifestations and a fundamental factor in overcoming the economic crisis, especially in the countries with emerging markets.

However, it should be noted that concerning the current economic development, the possibilities of the previous model of development and the manifestation of an imbalance in the economy, which is usually based on a rapid increase in domestic demand, have been largely exhausted [47,48]. In this context, referring to the concept of "creative destruction" $[49,50]$, competition is rather a force that destroys the existing market conditions than a tool for establishing market equilibrium. Since innovation becomes the main driving element of the current economic set-up and the main source of income generation, it forms a new pattern of the national economy. The new model of the economy requires more intensive use of all resources, structural modernization of the economy and ensures innovative development. At the same time, both the goals of socio-economic development and its conditions look completely different from what they looked after the previous crisis $[47,49,51,52]$. The crisis in the economy of any country is aggravated by the innovation crisis, which manifests itself in a sharp decrease in the controllability of the processes of creating and introducing innovations, in the absence of funding sources and the curtailment of the activities of research creative teams. Consequently, in these conditions, an economic crisis should be considered as an element for adjusting the financial and labor markets to technological and other amendments. Regarding this, the search for possible solutions to the problems of managing innovation processes becomes one of the most essential tasks of anti-crisis management, and, therefore, indicators of the country's innovative development should constitute an indicative system of crisis manifestations along with traditional oscillators of the monetary market [51].

\section{Data}

Since any crisis impacts economic development, the index of real GDP growth (indicator Y) was used as an indicator for the assessment of the cyclical development of the Russian economy and for the identification of structural changes in it. Indicator $Y$ is calculated as chained-dollar real GDP growth rates. The practicability of using this parameter as an indicator of economic development is confirmed by many publications, including [53-55]. The authors considered the time from 1995 to the first half of 2020 to calculate the real GDP growth indices. The use of the real GDP index indicator is determined by the following facts:

1. GDP is the main indicator that characterizes the level of economic development of a country

2. Real GDP allows us to exclude the price factor from time series

3. GDP in US dollars characterizes the country's competitiveness in world space and allows us to take into account the influence of the currency factor on the economic development

4. Index value can be applied for modeling, as it provides the comparability of indicators that have different units of measurement and categorial system. As a result, the statistical significance of the models is provided

An analysis of the dynamics of the real GDP growth (Figure 1) indicates the extreme values, which may result in a violation of the normal data distribution law that is a prerequisite for using most methods. Therefore, to check the data for a normal distribution is the primary task of economic crisis modeling and the factors that determine it. 


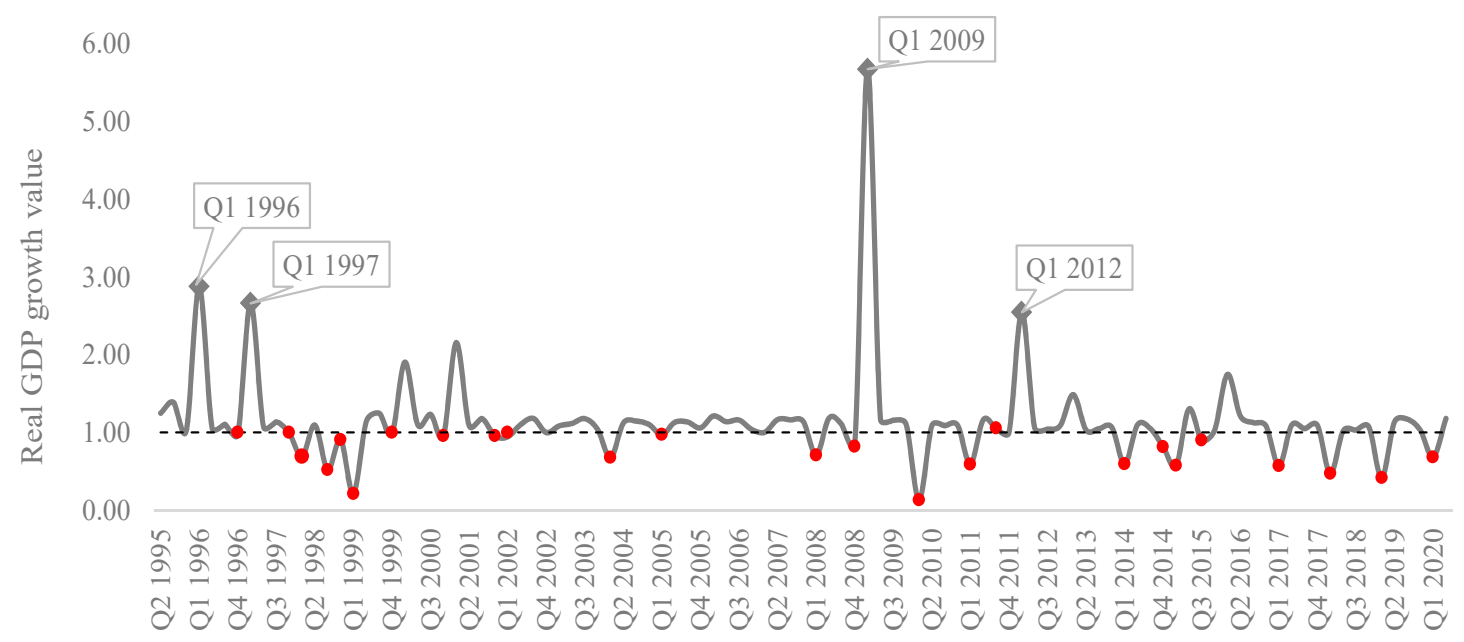

Figure 1. Dynamics of the Russian real GDP growth for the period from 1995 to the first half of 2020 [14]. Note: —extreme values that were excluded from the sample to ensure the normal distribution law, -recession points at which the real GDP growth index is below 1.0.

The growth and decline of the indicator in the 1st quarter during the following years: 1996, 1997, 1999, 2000, 2001, 2009, 2010, 2012, 2019 were possible and the most significant extreme values in terms of deviation from the average real GDP index for the period under study. The deviation of the real GDP index from the average for the period from 1995 to the first half of 2020 was 398.8\% for Q1 2009; with 153.2\% for Q1 1996; 134.2\% for Q1 1997; 123.8\% for Q1 2012, 89.4\% for Q1 2001 and $67.3 \%$ for Q1 2000. In Q1 1999, 2010, 2019, the value of the real GDP index was at a level lower than the average index for the period from 1995 to the first half of 2020. In modulus, the deviation value amounted to 88.7\% (Q1 2010), 81.3\% (Q1 1999), 63.4\% (Q1 2019).

Initial verification of the data by the Kolmogorov-Smirnov and Shapiro-Wilk tests in Statistica 10.0 program showed that the normal distribution law is refuted with a probability of $p<0.01$ (according to the Kolmogorov-Smirnov test) and of $p=0.00000$ (according to the Shapiro-Wilk test). To bring the data to the normal distribution law, extreme values were gradually eliminated (in proportion to the decrease in the real GDP index deviation for the appropriate quarter from the average value from 1995 to the first half of 2020). The elimination of extreme values continued until the real GDP index variable was brought to the normal distribution law. This method of bringing data to the normal distribution law is confirmed by research [56,57]. As a result, the following points shown in Figure 1 were excluded: Q1 2009, Q1 1996, Q1 1997 and Q1 2012.

Therefore, the normal law of distribution of the growth index of real GDP was ensured. The indicated data set, despite the exclusion of certain values, allows us to estimate the development of the economic crisis, since all the minimum values of the real GDP growth index for the studied period were used in the present work. According to the index dynamics (Figure 1 ) the recession in the economy was observed in the following periods: Q4 1996; Q4 1997; Q1, Q3 and Q4 1998; Q1 and Q4 1999; Q4 2000; Q4 2001; Q1 and Q4 2002; Q1 2004; Q1 2005; Q1 and Q4 2008; Q1 2010; Q1 and Q4 2011; Q1 and Q4 2014; Q1 and Q3 2015; Q1 2017; Q1 2018; Q1 2019 and Q1 2020 when the index value was below 1.0.

To check the data for structural shifts was the next stage of the research. Structural shifts contribute to the necessity to divide time series of indicators into segments in order to ensure the stationarity of the data. The absence of structural shifts eliminates this need. From economic point of view, the identification of structural changes simplifies the determination of the factors that caused it, basing on a more significant influence. The presence of structural shifts was verified by the Chow test. This test involves the development of linear regression models for supposedly heterogeneous subsamples of the indicators and verification of the statistical significance of the differences in the model residuals for these subsamples using F-statistics. The growth of the real GDP index in Q1 2009 
was the most significant extreme value. This date was taken as the point of dividing the data sample into two subsamples (Q2 1995-Q4 2008 and Q2 2009-Q2 2020) to check for structural shifts. A linear regression model was built based on smoothed data using the EViews 10 statistical package with the real GDP index as a dependent variable and time (the ordinal number of the timeframe) as an independent variable. The significance of the model is evidenced by the coefficient of determination 0.80 , the calculated values of t-Statistic ( 19.64 for the independent variable with a tabular value of 1.99 at a significance level of 0.05) and F-statistic for the model (385.62 with a tabular value of 3.95). The probability of rejecting the hypothesis about the statistical significance of the independent variable and the model as a whole is 0.00 . According to the Chow test results, the probability of accepting the null hypothesis about the absence of structural shifts is 0.678 . The excess of the calculated value over the critical value of 0.05 indicates the absence of structural shifts. The results of checking the data for structural shifts are given in Appendix A.

The diagnosis of the economic crisis was based on the hypothesis that the economic recession is caused by some financial factors. The scientists distinguish the following factors: the imbalance (increase/decrease) in bank loans (similar to the Latin American crisis of 1980 and Mexican in 1994); mortgage credits (crisis in Japan in the 1980s, in the USA in 2000-2001 and in the USA in 2007-2009) [20]; imbalance in savings (crisis in the USA in 1931 and in East Asia in 2000) [19,20]; currency devaluation (crisis in Asia in 1997-1998). In addition, the authors highlighted the following causes of economic crises: a decrease in government bond yields, a state budget deficit [19]; an increase in interest rates, fall of stock, credit rating downgrade [20]; a decrease in foreign-exchange and gold reserves, an outflow of international investment [2,21,23]; an external debt increase [20]; a change in the money supply and its aggregates, as well as a monetary base; an increase in ratio of non-performing loans and bad loans [2,4] change in the amount of debt support payments and estimate of the obligatory repayment of the loan principal comparing to incomes [21]; changes in the ratio of loans to households and non-financial organizations comparing to the deposits and settlement accounts of the population and non-financial organizations [20], decrease in investment and innovation activity [48,51]. For Russia, the Federal Budget revenues for 2019 were formed at the expense of oil and gas revenues by $39.25 \%$ [57], which indicates a significant dependence of the economy on the oil and gas sector. In this regard, the fall in oil prices is an additional factor that can provoke an economic crisis. The significance of the influence of this factor on Russia's economic development is confirmed in Reference [25,26].

The list of indicators that were regarded as predictors of the economic crisis in Russia was formed with the system of following indicators:

- $\quad \mathrm{X} 1$-index of the bank loan growth [58]

- $\quad \mathrm{X} 2$-index of the mortgage growth [58]

- $\quad \mathrm{X} 3$-index of the bank savings [58]

- $\quad X 4$-index of USD/RUD rate [58]

- X5-index of the government bond yield [59]

- $\quad$ X6-the ratio of the deficit (surplus) of the consolidated budget to GDP $[14,60]$

- $\quad$ X7-key rate index (up to Q4 2013, that is, refinancing rate) [58]

- X8-the growth rate of Moscow Exchange Index [59]

- $\quad$ X9-the growth rate of Russian Trading System (RTS) Index [59]

- X10 - dynamics of positions of the sovereign credit rating of the Russian Federation [58]

- $\quad \mathrm{X} 11$ - the index of foreign-exchange and gold reserves growth [58]

- $\quad \mathrm{X} 12$ - indicator of the ratio of the balance of gross foreign investment to GDP (the difference between the volume of gross foreign investment into the country and the investment from the country) [14]

- X13-the index of gross external debt [60]

- $\quad \mathrm{X} 14-$ money growth index [58]

- $\quad$ X15-growth rate of non-performing and bad loans [58] 
- X16 - the ratio of the amount of payments for debt servicing and the assessment of the amount of obligatory repayment for the principal of the loan to disposable income of the population [60]

- $\quad$ X17-the ratio of monetary base to nominal GDP [14]

- X18-the ratio of loans to the population and non-financial organizations to deposits and settlement accounts of the population and non-financial organizations [58]

- X19-the ratio of M2 to the amount of bank loans to households and non-financial organizations [58]

- $\quad \mathrm{X} 20$ - the growth index for domestic spending on R\&D expressed as a percentage of GDP [14]

- $\quad \mathrm{X} 21$ - the growth index for the indicator of organizations' innovative activities [14]

- $\quad \mathrm{X} 22$ - the growth index for the inventive activity coefficient-the number of domestic patent applications for inventions filed in Russia, per 10 thousand people [14]

- X23-the growth index for capital investment costs (in US dollars) [14]

- X24-the growth rate of global Brent crude oil price [61]

For this purpose, the Moody's rating was used, which involves 21 positions (from C to Aaa-in order of the positions improvement). Since rating is not characterized by a quantitative assessment, a point assessment was implemented in the study, assuming the following:

1. A country was assigned a score in accordance with a credit rating. The higher the credit rating is, the higher the score is: $\mathrm{C}-1$ score, $\mathrm{Ca}-2, \mathrm{Caa} 3-3, \mathrm{Caa}-4, \mathrm{Caa} 1-5, \mathrm{~B} 3-6, \mathrm{~B} 2-7, \mathrm{~B} 1-8$, Ba3-9, Ba2-10, Ba1-11, Baa3-12, Baa2-13, Baa1-14, A3-15, A2-16, A1-17, Aa3-18, Aa2-19, Aa1-20, Aaa-21

2. Dynamics is calculated as an absolute variation of score compared to the previous period. Relative indicators (growth, growth) are not used in this case, since if the rating changes by 1 position, the growth rate will be higher at the lower levels of the rating than at the highest with an equivalent change; Relative indicators (growth rate and accession rate) are not applied in this case, since if the rating changes by 1 position, the growth (accession) rate is getting higher at the lower levels of the rating than at the highest levels with an equivalent variation

The use of relative values in the analysis contributes to the indicators commensurability and modeling result adequacy. All indices are calculated by means of the chain method for the dynamics series calculation. For indicators X6, X12, the indices were not calculated since the indicators of the balance of the budget and investments can take positive and negative value; for X16-X24 the indices were not calculated due to the fact that these indicators are relative.

The list of indicators X1-X23 is based on the narrowing of the expert group, which consists of 45 representatives of the Ministry of Finance of the Russian Federation, the Ministry of Economic Development of the Russian Federation and the National Rating Agency, whose competence includes analysis of the economic situation, analysis of the banking sector, budget conditions, assessment of the country's solvency and forecasting probability the onset of economic crises. The experts' assessment was performed in two stages:

- At the 1st stage, the experts proposed a list of indicators-indicators of the economic crisis, from which the indicator system X1-X24 was formed

- Due to the fact that at the 1st stage individual assessments were used, which differed in some indicators, at the 2nd stage the generalized system of indicators X1-X24 was checked by experts from the standpoint of its completeness and representativeness as leading indicators of the economic crisis. The experts estimated the completeness of the proposed indicator system by an average of 9.96 points out of 10 maximum; the representativeness of each indicator by experts was estimated at $9.33-10$ points (93-100\% of the maximum level), which indicates the possibility of using indicators $\mathrm{X} 1-\mathrm{X} 23$ in determining indicators of the economic crisis and the strength of their impact on the real GDP index

The reliability of the results of expert assessment is confirmed by the competence of experts, the experience of each of which in this field exceeds 10 years; the consistency of their opinions, 
estimated using the coefficient of variation, the value of which according to individual estimates of the completeness and representativeness of the indicators does not exceed $5 \%$.

Due to the fact that the given research modeling assumes stationarity of the investigated time series, the values of $\mathrm{Y}, \mathrm{X} 1-\mathrm{X} 24$ indicators for the investigated period are checked for stationarity using the extended Dickey-Fuller method in the EViews 10.0 software (Table 1).

Table 1. Estimation of the stationarity of Russia's real GDP index and leading indicators of the economic crisis for the period from 1995 to the first half of 2020 according to the extended Dickey-Fuller test [14,58-61].

\begin{tabular}{cccccc}
\hline Indicator & Specification & Prob. & Indicator & Specification & Prob. \\
\hline Y & I, 0 & 0.0006 & X13 & I, 1 & 0.0077 \\
X1 & I, 1 & 0.0004 & X14 & I, 0 & 0.0013 \\
X2 & I, 1 & 0.0011 & X15 & I, 1 & 0.0002 \\
X3 & I, 0 & 0.0167 & X16 & I, 1 & 0.0093 \\
X4 & I, 1 & 0.0010 & X17 & I, 0 & 0.0021 \\
X5 & I, 0 & 0.0016 & X18 & I, 0 & 0.0000 \\
X6 & I, 0 & 0.0142 & X19 & I, 0 & 0.0001 \\
X7 & I, 1 & 0.0000 & X20 & I, 1 & 0.0014 \\
X8 & I, 1 & 0.0279 & X21 & I, 0 & 0.0008 \\
X9 & I, 0 & 0.0014 & X22 & I, 1 & 0.0016 \\
X10 & I, 1 & 0.0006 & X23 & I, 1 & 0.0180 \\
X11 & I, 0 & 0.0074 & X24 & I, 0 & 0.0000 \\
X12 & I, 0 & 0.0086 & & &
\end{tabular}

Note: Prob.--the probability of accepting the null hypothesis that the time series is non-stationary; I-Intercept-time series specification with respect to constant; 0 -level; 1 -1st differencing.

All indicators are stationary at a particular specification. Indicators $\mathrm{Y}, \mathrm{X} 3, \mathrm{X} 5, \mathrm{X6}, \mathrm{X9}, \mathrm{X} 11, \mathrm{X12}$, $\mathrm{X} 14, \mathrm{X} 17-\mathrm{X} 19, \mathrm{X} 21, \mathrm{X} 24$ are stationary at specification $(\mathrm{I}, 0)$. The time series data of these indicators are stationary without additional integration. The probability of accepting the null hypothesis that time series is non-stationary does not exceed $5 \%$ (Prob < 0.05). The indices X1, X2, X4, X7, X8, X10, X13, $\mathrm{X} 15, \mathrm{X} 16, \mathrm{X} 20, \mathrm{X} 22, \mathrm{X} 23$ are stationary at the specification (I, 1). These parameters were normalized to stationarity using first order integration. Thus, the probability of adopting the null hypothesis that a time series is non-stationary for all indices does not exceed 5\% and therefore, with $95 \%$ probability the stationarity of time series can be stated.

\section{Methods}

The study of the cyclical development of the Russian economy was carried out using the Fourier spectral analysis method in the Statistica 10.0 program. The authors applied the value of the real GDP growth index of the Russian Federation for the period from 1995 to the first half of 2020 with quarterly specification. According to the spectral analysis, the cycles are selected applying the decomposition of the time series into sinusoidal functions. This type of analysis enables to recognize cyclical fluctuations of different, previously unknown length [62,63]. In this study, the purpose of the spectral analysis was to identify fluctuations of certain periodicity in the dynamics of the real GDP index, which may indicate the influence of cyclical factors on the dynamics of economic development. In the case of cycles, appropriate transformations of time series are necessary to exclude their influence or the selection of another methodological toolkit to study the factors that are leading indicators of an economic crisis. In the absence of cycles, no additional transformations have been made.

The study of the factors that impact the dynamics of economic development and the formation of neural network models was carried out on the basis of the data distribution for the period from 1995 to the first half of 2020 that were modified to the normal law of distribution (except of extreme values for Q1 2009, Q1 1996, Q1 1997 and Q1 2012). The statistical data system was checked for cause and effect relationships using the Granger test $[64,65]$ in the EViews 10.0 software package. According to the test results, the authors developed the neural network models of the influence of indicators of the 
economic crisis on the economic situation in the Statistica 10.0 program. This method provides the possibility of modeling more complex relationships, compared to the multiple linear regression method, which is confirmed by its use in assessing and forecasting crisis phenomena in the economy $[66,67]$. When constructing a neural network, the error backpropagation algorithm was used, which belongs to the supervised learning method and assumes the presence of the resulting variable value. In this research, it is the real GDP growth rate. According to the chosen method, the input pulse passes direct (from the network input to the output) and return paths (from the output to the input). On the direct path, an output vector is formed that corresponds to the current state of the neuron weights. On the return path, the neuron weights are corrected based on the criterion of minimizing the network output error and reaching the accepted level of approximation for the actual and predicted values of the resulting variable [68].

The neural network model of the influence of leading indicators of the economic crisis is introduced with the function

$$
y=f\left(X_{i}\right)
$$

where by

$$
\frac{1}{2} \sum_{j=1}^{p}\left(y_{j}-d_{j}\right)^{2} \rightarrow 0,
$$

where: $y$ is dependent variable that corresponds to the index of real GDP; $f\left(X_{i}\right)$ is an activation function; $X_{i}$ are independent factors, that is, variables $\mathrm{X} 1-\mathrm{X} 24$ that impact the economic development; $y_{j}$ is the value of the $j$ output of the neural network; $d_{j}$ is a target value of $j$ output; $p$ is the number of neurons in the output layer. The authors implemented neural networks of the multilayer perceptron type. Therefore, the Function (1) takes the following form:

$$
y=f(h(n)),
$$

where: $h(n)$ is the output pulse of the $\mathrm{n}$ neurons layer, that is, the result of converting the values of independent factors $\left(X_{i}\right)$ into the output pulse, taking into account the synapse and noise. Output pulse function is written as follows:

$$
h(n)=f(W(n-1) \times H(n-1)+B(n-1)),
$$

where: $W$ is a neural network synapse weights vector, $H$ is a vector of output pulses, $B$ is a noise vector.

For the development of a neural network, a system of factors $X_{i}$ was used that fulfill the condition:

$$
y_{t}=a_{0}+\Sigma \alpha_{k} \times y_{t-k}+\Sigma \beta k \times\left(X_{i}\right)_{t-k}+\varepsilon_{t}
$$

For

$$
\beta_{k} \neq 0,
$$

where: $a_{0}, \alpha_{k}, \beta_{k}$ are the regression coefficients; $\varepsilon_{t}$ is an error; $(t-k)$ is a time lag.

In accordance with the developed neural network, the elasticity coefficients for the variations of the level of economic development were calculated. The independent variable values $\left(X_{i}+1 \%\right)$ were substituted into the developed neural network, where: $1 \%$ is the growth of the $i$ factor by $1 \%$. The following values were applied for the indicator $X_{i}$ :

- $\quad$ Minimum value of the $i$-factor for the period from 1995 to $2020\left(X_{i \min }\right)$

- Average value $\left(\overline{X_{i}}\right)$

- $\quad$ Maximum value $\left(X_{i \max }\right)$ 


\section{Results}

The results of spectral analysis (Table 2) were used to determine that the dynamics of Russia's real GDP index for the period from 1995 to the first half of 2020 has the greatest probability of identifying cycles with a duration of 2-3,16,3-4, 19-20 quarters. The periods are specified in the order of decreasing probability of identifying statistically significant cycles. For these periods, the highest values of the "Periodogram" indicator, which characterizes the spectral density of the studied time series. For the period of 2.233 quarters, the periodogram value was 0.634 , with 0.455 for 16 quarters, 0.416 for 3.429 quarters, 0.394 for 19.2 quarters and 0.346 for 2.4 quarters.

Table 2. Indicators of the spectral analysis of the dynamics of the Russian real GDP index for the period from 1995 to the first half of 2020 [14].

\begin{tabular}{cccccccc}
\hline Frequency & Period & Periodogram & Density & Frequency & Period & Periodogram & Density \\
\hline 0.448 & 2.233 & 0.634 & 0.332 & 0.271 & 3.692 & 0.092 & 0.173 \\
0.063 & 16.000 & 0.455 & 0.321 & 0.313 & 3.200 & 0.086 & 0.140 \\
0.292 & 3.429 & 0.416 & 0.277 & 0.198 & 5.053 & 0.080 & 0.116 \\
0.052 & 19.200 & 0.394 & 0.354 & 0.135 & 7.385 & 0.076 & 0.061 \\
0.417 & 2.400 & 0.346 & 0.178 & 0.365 & 2.743 & 0.076 & 0.054 \\
0.156 & 6.400 & 0.315 & 0.149 & 0.115 & 8.727 & 0.073 & 0.053 \\
0.083 & 12.000 & 0.306 & 0.170 & 0.094 & 10.667 & 0.061 & 0.111 \\
0.344 & 2.909 & 0.300 & 0.157 & 0.427 & 2.341 & 0.049 & 0.163 \\
0.479 & 2.087 & 0.299 & 0.235 & 0.333 & 3.000 & 0.045 & 0.148 \\
0.042 & 24.000 & 0.276 & 0.249 & 0.396 & 2.526 & 0.038 & 0.044 \\
0.260 & 3.840 & 0.249 & 0.183 & 0.031 & 32.000 & 0.037 & 0.138 \\
0.240 & 4.174 & 0.240 & 0.186 & 0.125 & 8.000 & 0.036 & 0.054 \\
0.490 & 2.043 & 0.218 & 0.184 & 0.385 & 2.595 & 0.035 & 0.035 \\
0.323 & 3.097 & 0.217 & 0.144 & 0.104 & 9.600 & 0.030 & 0.058 \\
0.281 & 3.556 & 0.215 & 0.232 & 0.375 & 2.667 & 0.026 & 0.040 \\
0.219 & 4.571 & 0.208 & 0.163 & 0.010 & 96.000 & 0.026 & 0.054 \\
0.469 & 2.133 & 0.199 & 0.197 & 0.458 & 2.182 & 0.024 & 0.227 \\
0.188 & 5.333 & 0.172 & 0.106 & 0.177 & 5.647 & 0.023 & 0.067 \\
0.021 & 48.000 & 0.166 & 0.099 & 0.406 & 2.462 & 0.023 & 0.106 \\
0.438 & 2.286 & 0.144 & 0.242 & 0.146 & 6.857 & 0.018 & 0.104 \\
0.250 & 4.000 & 0.141 & 0.188 & 0.354 & 2.824 & 0.008 & 0.097 \\
0.302 & 3.310 & 0.138 & 0.198 & 0.073 & 13.714 & 0.007 & 0.203 \\
0.208 & 4.800 & 0.126 & 0.136 & 0.167 & 6.000 & 0.004 & 0.090 \\
0.229 & 4.364 & 0.118 & 0.170 & & & & \\
\hline
\end{tabular}

The Kolmogorov-Smirnov test was used to check the statistical significance of potentially possible cycles (Figure 2). This test helped verify the exponential law of the periodogram value distribution for the Russian real GDP growth rate for the period from 1995 to the first half of 2020.

If there are cycles of a certain periodicity in the dynamics of the Russian real GDP growth rate, the exponential law should be rejected for the periodogram values distribution. The calculated value of the Kolmogorov-Smirnov test is 0.0932 (Figure 2), the tabular value is 0.1358 at a significance level of 0.05 . The calculated value is below the tabular value. This means that the periodogram histogram follows an exponential distribution. In the investigated time series, there are no statistically significant fluctuations of a certain periodicity, which help predict the onset of a crisis based only on the dynamics of the time series of the studied indicator, without taking into account additional factors of influence. The absence of such fluctuations necessitated the research of leading indicators of the economic crisis. 
Spectral analysis: Russian real GDP index

No. of cases: 96

Kolmogorov-Smirnov test: 0.0932

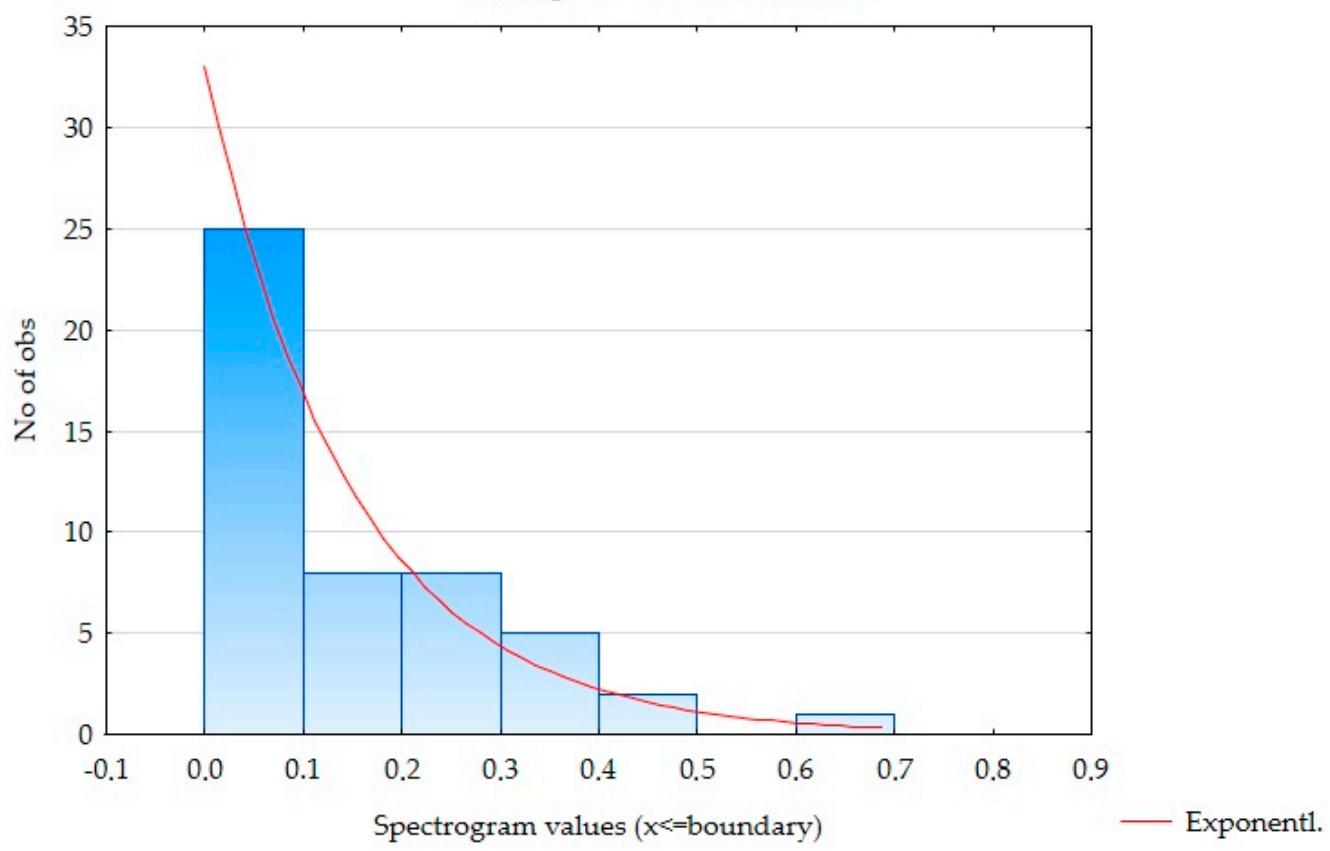

Figure 2. Results of the exponential law verification of the periodogram values distribution for the Russian real GDP growth indicator from 1995 to the first half of 2020.

The absence of periodicity in the economy development means that the dynamics of economic development and the uprising crises are mostly influenced by "unplanned" (non-periodic) factors, represented by X1-X24 factors. In order to assess this impact, the Granger causality test was conducted with a lag from Q1 to Q4 $(\mathrm{L}=1, \ldots$ 4). It was determined that in the time from 1995 to the first half of 2020, indicator X10 was a result of the influence of other indicators of the economic crisis (X1-X9, X11-X24) (Table 3). The probability of the hypothesis confirmation about the absence of the influence of indicators $\mathrm{X} 1-\mathrm{X} 9, \mathrm{X} 11-\mathrm{X} 24$ on $\mathrm{X} 10$ did not exceed $4 \%$. This is because a sovereign credit rating is based on the status of the balance of payments and stocks, debt level, financial assets yield and budget security, depends on investment and innovation. Therefore, the consideration of the indicator $\mathrm{X} 10$ as a factor that contributes to economic crisis is impractical due to different detail level.

Table 3. Statistically significant (at $p=0.05$ ) causal relationships between Russia's real GDP index and the leading indicators of the economic crisis from 1995 to the first half of 2020 [14,58-61].

\begin{tabular}{|c|c|c|c|c|c|}
\hline $\begin{array}{c}\text { Direction of the } \\
\text { Causal Relationship }\end{array}$ & Prob. & $\begin{array}{l}\text { Direction of the } \\
\text { Causal Relationship }\end{array}$ & Prob. & $\begin{array}{l}\text { Direction of the } \\
\text { Causal Relationship }\end{array}$ & Prob. \\
\hline \multicolumn{6}{|c|}{ Causal Relationships between the Economic Crisis Indicators } \\
\hline $\mathrm{X} 1 \rightarrow \mathrm{X} 10$ & $0.0168(\mathrm{~L}=1)$ * & $\mathrm{X} 7 \rightarrow \mathrm{X} 10$ & $0.0270(\mathrm{~L}=2)$ & $\mathrm{X} 16 \rightarrow \mathrm{X} 10$ & $0.0199(\mathrm{~L}=2)$ \\
\hline $\mathrm{X} 1 \rightarrow \mathrm{X} 15$ & $0.0023(\mathrm{~L}=1)$ & $\mathrm{X} 7 \rightarrow \mathrm{X} 12$ & $0.0056(\mathrm{~L}=2)$ & $\mathrm{X} 17 \rightarrow \mathrm{X} 10$ & $0.0401(\mathrm{~L}=2)$ \\
\hline $\mathrm{X} 2 \rightarrow \mathrm{X} 10$ & $0.0094(\mathrm{~L}=1)$ & $\mathrm{X} 7 \rightarrow \mathrm{X} 14$ & $0.0103(\mathrm{~L}=2)$ & $\mathrm{X} 18 \rightarrow \mathrm{X} 10$ & $0.0098(\mathrm{~L}=2)$ \\
\hline $\mathrm{X} 3 \rightarrow \mathrm{X} 10$ & $0.0187(\mathrm{~L}=2)$ & $\mathrm{X} 7 \rightarrow \mathrm{X} 18$ & $0.0335(\mathrm{~L}=2)$ & $\mathrm{X} 19 \rightarrow \mathrm{X} 10$ & $0.0291(\mathrm{~L}=2)$ \\
\hline $\mathrm{X} 4 \rightarrow \mathrm{X} 10$ & $0.0069(\mathrm{~L}=1)$ & $\mathrm{X} 7 \rightarrow \mathrm{X} 19$ & $0.0400(\mathrm{~L}=2)$ & $\mathrm{X} 20 \rightarrow \mathrm{X} 10$ & $0.0047(\mathrm{~L}=3)$ \\
\hline $\mathrm{X} 5 \rightarrow \mathrm{X} 10$ & $0.0001(\mathrm{~L}=2)$ & $\mathrm{X} 8 \rightarrow \mathrm{X} 10$ & $0.0399(\mathrm{~L}=2)$ & $\mathrm{X} 20 \rightarrow \mathrm{X} 21$ & $0.0094(\mathrm{~L}=1)$ \\
\hline $\mathrm{X} 6 \rightarrow \mathrm{X} 10$ & $0.0029(\mathrm{~L}=2)$ & $\mathrm{X} 9 \rightarrow \mathrm{X} 10$ & $0.0400(\mathrm{~L}=2)$ & $\mathrm{X} 20 \rightarrow \mathrm{X} 22$ & $0.0082(\mathrm{~L}=1)$ \\
\hline $\mathrm{X} 7 \rightarrow \mathrm{X} 1$ & $0.0364(\mathrm{~L}=2)$ & $\mathrm{X} 11 \rightarrow \mathrm{X} 10$ & $0.0091(\mathrm{~L}=2)$ & $\mathrm{X} 21 \rightarrow \mathrm{X} 10$ & $0.0104(\mathrm{~L}=3)$ \\
\hline $\mathrm{X} 7 \rightarrow \mathrm{X} 2$ & $0.0054(\mathrm{~L}=2)$ & $\mathrm{X} 12 \rightarrow \mathrm{X} 10$ & $0.0311(\mathrm{~L}=2)$ & $\mathrm{X} 22 \rightarrow \mathrm{X} 10$ & $0.0200(\mathrm{~L}=3)$ \\
\hline $\mathrm{X} 7 \rightarrow \mathrm{X} 3$ & $0.0009(\mathrm{~L}=2)$ & $\mathrm{X} 13 \rightarrow \mathrm{X} 10$ & $0.0199(\mathrm{~L}=2)$ & $\mathrm{X} 23 \rightarrow \mathrm{X} 10$ & $0.0007(\mathrm{~L}=3)$ \\
\hline $\mathrm{X} 7 \rightarrow \mathrm{X} 4$ & $0.0075(\mathrm{~L}=2)$ & $\mathrm{X} 14 \rightarrow \mathrm{X} 10$ & $0.0035(\mathrm{~L}=2)$ & $\mathrm{X} 24 \rightarrow \mathrm{X} 10$ & $0.0416(\mathrm{~L}=2)$ \\
\hline $\mathrm{X} 7 \rightarrow \mathrm{X} 5$ & $0.0094(\mathrm{~L}=2)$ & $\mathrm{X} 15 \rightarrow \mathrm{X} 10$ & $0.0137(\mathrm{~L}=2)$ & & \\
\hline
\end{tabular}


Table 3. Cont.

\begin{tabular}{|c|c|c|c|c|c|}
\hline $\begin{array}{c}\text { Direction of the } \\
\text { Causal Relationship }\end{array}$ & Prob. & $\begin{array}{l}\text { Direction of the } \\
\text { Causal Relationship }\end{array}$ & Prob. & $\begin{array}{l}\text { Direction of the } \\
\text { Causal Relationship }\end{array}$ & Prob. \\
\hline \multicolumn{6}{|c|}{ Causal Relations between the Economic Crisis Indicators and the Real GDP Index } \\
\hline $\mathrm{X} 1 \rightarrow \mathrm{Y}$ & $0.0084(\mathrm{~L}=2)$ & $\mathrm{X} 10 \rightarrow \mathrm{Y}$ & $0.0028(\mathrm{~L}=1)$ & $\mathrm{X} 21 \rightarrow \mathrm{Y}$ & $0.0099(\mathrm{~L}=3)$ \\
\hline $\mathrm{X} 2 \rightarrow \mathrm{Y}$ & $0.0100(\mathrm{~L}=2)$ & $\mathrm{X} 12 \rightarrow \mathrm{Y}$ & $0.0009(\mathrm{~L}=3)$ & $\mathrm{X} 22 \rightarrow \mathrm{Y}$ & $0.0130(\mathrm{~L}=3)$ \\
\hline $\mathrm{X} 4 \rightarrow \mathrm{Y}$ & $0.0003(\mathrm{~L}=2)$ & $\mathrm{X} 15 \rightarrow \mathrm{Y}$ & $0.0312(\mathrm{~L}=2)$ & $\mathrm{X} 23 \rightarrow \mathrm{Y}$ & $0.0041(\mathrm{~L}=3)$ \\
\hline $\mathrm{X} 7 \rightarrow \mathrm{Y}$ & $0.0169(\mathrm{~L}=2)$ & $\mathrm{X} 20 \rightarrow \mathrm{Y}$ & $0.0012(\mathrm{~L}=3)$ & $\mathrm{X} 24 \rightarrow \mathrm{Y}$ & $0.0101(\mathrm{~L}=2)$ \\
\hline
\end{tabular}

Note: *-statistically significant time lag (L) that corresponds to the number of quarters of the delay in the influence of independent variables on dependent ones. In the case of the significance of causal relations between indicators at more than one lag value, the lag indicated in the table corresponds to the minimum value of the "Prob.," that is, the most significant impact.

The results of the Granger causality test are shown in Table 3, they evidenced the presence of the following chains of causal relationships between the indicators of an economic crisis. The growth of granted bank loans (indicator X1) leads to an increase in the share of non-performing and bad loans (X15); the less effective management of banks' credit risks and the less justified the decision to grant loans, the more significant the causal relationship is.

The key interest rate of the Central Bank is the main instrument of monetary policy aimed at regulating the money supply. An increase in the key interest rate (X7) leads to the increased cost of loans attracted by a commercial bank and, accordingly, to rising interest for loans provided by commercial banks, a decrease in the lending amount in general (X1) and mortgage lending in particular (X2). On the other hand, rising key rate and loan interest make it possible to increase the deposit rate while maintaining the existing margin, which will lead to an increase in bank savings (X3). A decrease in lending amounts and an increase in savings leads to a decrease in the loan-to-deposit ratio (X18) and a decrease in the money supply (X14, X19).

Provided that the country's macroeconomic state remains unchanged, rising key interest rate results in an increase in its investment attractiveness and, as a consequence, an increase in the balance of foreign direct investment (X12) and to the revaluation of the national currency (X4).

A rising key interest rate may have an opposite effect on bond yields (X5) depending on the type of bond. An increase in the key rate reduces the yield on old fixed coupon bond issues and makes them less attractive compared to other ways of saving, for example, bank deposits. At the same time, the yield of variable coupon bonds and newly issued bonds grows.

A causal chain was also revealed between the indicators of innovative activity: X20 $\rightarrow$ X21, X20 $\rightarrow$ X22. The growth of gross domestic spending on R\&D leads to an increase in the indicator of organizations' innovative activities and an increase in the number of domestic patent applications for inventions as a result of funding expansion.

According to the study of causal relationships between leading indicators of the economic crisis and the real GDP index, it was determined that for the Russian economy, studied for the period from 1995 to the first half of 2020, the crisis indicators are monetary factors that determine economic activity: indicators of the bank loan growth rate, the amount of mortgage lending, the share of non-performing and bad loans, the exchange rate and the key interest rate. In addition to monetary factors, the dynamics of real GDP is influenced by the factors of investment (the indicator of the ratio of the foreign direct investment balance to GDP, the capital investment growth rate) and innovation (the growth index for domestic spending on research and development (R\&D), the growth index of the inventive activity coefficient, the growth index of the organizations' innovative activity) activities.

The global oil price index is another factor influencing the dynamics of economic development as a result of the significant dependence of the Russian economy on the revenues from the oil and gas sector.

Neural network models were developed to determine the influence of the economic crisis indicators on the economic situation (Table 4). 
Table 4. Characteristics of neural models for the impact of the economic crisis indicators on the level of Russia's real GDP from 1995 to the first half of 2020 [14,58-61].

\begin{tabular}{ccccccc}
\hline $\begin{array}{c}\text { Dependent } \\
\text { Variable }\end{array}$ & $\begin{array}{c}\text { Independent } \\
\text { Variable }\end{array}$ & Model Type & $\begin{array}{c}\text { Training } \\
\text { Error }\end{array}$ & Test Error & $\begin{array}{c}\text { Validation } \\
\text { Error }\end{array}$ & Sensitivity \\
\hline Y & X1 & MLP 1-3-1 & 0.0036 & 0.0001 & 0.0002 & 3.97 \\
Y & X2 & MLP 1-2-1 & 0.0048 & 0.0006 & 0.0007 & 3.24 \\
Y & X4 & MLP 1-6-1 & 0.0002 & 0.0007 & 0.0009 & 4.82 \\
Y & X7 & MLP 1-8-1 & 0.0168 & 0.0000 & 0.0004 & 2.29 \\
Y & X12 & MLP 1-3-1 & 0.0010 & 0.0009 & 0.0018 & 3.54 \\
Y & X15 & MLP 1-4-1 & 0.0118 & 0.0011 & 0.0009 & 2.06 \\
Y & X20 & MLP 1-6-1 & 0.0102 & 0.0021 & 0.0009 & 2.13 \\
Y & X21 & MLP 1-8-1 & 0.0117 & 0.0010 & 0.0007 & 1.97 \\
Y & X22 & MLP 1-3-1 & 0.0084 & 0.0002 & 0.0003 & 2.02 \\
Y & X23 & MLP 1-3-1 & 0.0092 & 0.0004 & 0.0003 & 3.09 \\
Y & X24 & MLP 1-5-1 & 0.0109 & 0.0012 & 0.0010 & 2.66 \\
\hline
\end{tabular}

The developed neural networks of the multilayer perceptron type with one hidden layer are characterized by statistical significance, which is confirmed by the values of Training, Test and Validation error that do not exceed $5 \%$. The percentage of deviation of the values of the dependent variable calculated by neural networks from the actual values for the period of the study is $1.8-3.6 \%$. Percentage of deviation does not exceed $5 \%$, which indicates the adequacy of the built models and the possibility of their further use.

The influence power of a particular indicator on the economic development is estimated with the sensitivity indicator. According to the values of this indicator, the dynamics of the ruble exchange rate (indicator X4), the bank loan growth rate (X1), the indicator of the FDI-to-GDP balance ratio (X12), the mortgage lending growth rate $(X 2)$ and the growth rate of capital investment costs (X23) have the greatest influence on the dynamics of Russia's real GDP index. The sensitivity indicator for these indicators is the highest in absolute magnitude.

According to the results presented in Table 3, the "double" effect on the real GDP index is performed by indicator X7 (directly and by means of indicators X1-X5), X1 (directly and by means of X15) and X20 (directly and by means of X21, X22). Since there observed the multicollinearity between the economic crisis indicators, the study of the influence of all these indicators on indicator $\mathrm{Y}$ is impractical, as well as reducing the reliability of the modeling results. The most significant independent variables include paired coefficients of correlation between the following indicators:

- The key interest rate (X7) and bank loan growth rate (X1) — the value of the paired correlation coefficients is $|0.84|$

- $\quad$ The key interest rate $(X 7)$ and the mortgage lending growth rate $(X 2)-|0.69|$

- The key interest rate (X7) and RUB/USD exchange rate (X4)- $-0.75 \mid$

- The bank loan growth rate (X1) and non-performing and bad loan share growth rate (X15) - $|0.66|$

- The growth index for domestic spending on R\&D expressed as a percentage of GDP (X20) and the growth index for the indicator of organizations' innovative activities (X21) - $|0.70|$

- The growth index for domestic spending on R\&D expressed as a percentage of GDP (X20) and the growth index for the inventive activity coefficient (X22)- $|0.72|$

Data introduced in Table 4 indicate that the least significant effect on the resulting indicator among the 1st group of correlated factors is performed by X7. Therefore, in order to avoid multicollinearity, the indicator $\mathrm{X} 7$ was excluded from the model. Its influence was reflected through indicators $\mathrm{X} 1$, $\mathrm{X} 2, \mathrm{X} 4$, as more statistically significant. In the 2 nd group of correlated factors $(\mathrm{X} 1, \mathrm{X} 15), \mathrm{X} 15$ is less statistically significant factor in terms of elasticity. Therefore, its implementation in the model is not relevant. In the 3rd group (X20-X22), the X20 indicator exerts the most significant impact on the change in the resulting indicator. The elasticity of the $\mathrm{Y}$ indicator from $\mathrm{X} 20$ is 2.13, while from other correlated 
indicators it is 1.97 (from X21) and 2.02 (from X22). In this regard, X21 and X22 are excluded from the 3rd group of correlated indicators.

The reaction of the economy to a change in indicators $\mathrm{X} 1, \mathrm{X} 2, \mathrm{X} 4, \mathrm{X} 24$ is performed with a lag of two quarters, to a change in X12, X20, X23 with a lag of three quarters. According to these indicators, a neural network of the integral influence of factors $\mathrm{X} 1, \mathrm{X} 2, \mathrm{X} 4, \mathrm{X} 12, \mathrm{X} 20, \mathrm{X} 23, \mathrm{X} 24$ on the real GDP index was developed. It is characterized by the following data: model type is MLP 7-3-6-1, Training error $=0.0106$, Test error $=0.0038$, Validation error $=0.0030$. The percentage of deviation of the model-calculated values of the dependent variable from the actual values is $2.2-4.6 \%$.

The use of different values of the indicator $X_{i}$ is caused by the fact that neural networks provide simulation of the economic process according to the changing trends and patterns of its development, as well as the various impacts on the resulting indicator. The elasticity coefficients calculated in this way are introduced in Table 5.

Table 5. Values of elasticity coefficients of the real GDP index for leading indicators of the economic crisis [14,58-61].

\begin{tabular}{cccc}
\hline \multirow{2}{*}{ Independent Variable } & \multicolumn{2}{c}{ The Value of Elasticity Coefficients Depending on the Values of $\boldsymbol{X}_{\boldsymbol{i}}, \boldsymbol{\%}$} \\
\cline { 2 - 4 } & $\boldsymbol{X}_{\boldsymbol{i}}=\boldsymbol{X}_{\boldsymbol{i} \text { min }}$ & $\boldsymbol{X}_{\boldsymbol{i}}=\overline{\boldsymbol{X}_{\boldsymbol{i}}}$ & $\boldsymbol{X}_{\boldsymbol{i}}=\boldsymbol{X}_{\boldsymbol{i} \text { max }}$ \\
\hline X1 & +0.97 & +0.81 & -0.77 \\
X2 & +0.83 & +0.70 & -0.79 \\
X4 & -0.83 & -0.96 & -1.19 \\
X12 & +0.84 & +0.92 & +0.96 \\
X20 & +0.55 & +0.64 & +0.66 \\
X23 & +0.89 & +0.90 & +0.92 \\
X24 & +0.57 & +0.66 & +0.71 \\
\hline
\end{tabular}

The elasticity of the real GDP index for indicator $\mathrm{X} 1$ at minimum level of indicator $\mathrm{X} 1\left(\mathrm{X}_{i_{\text {max }}}\right)$, calculated by means of the model of the integral influence of factors, is $+0.97 \%$, at an average level $\left(\overline{X_{i}}\right)$ it comprises $+0.81 \%$ and at maximum level $\left(X_{i \max }\right)$ it corresponds to $-0.77 \%$ (Table 5$)$. Similar situation is with the indicator $\mathrm{X} 2$. Indicator increase at the minimum and average levels provide a positive effect on economic development of the Russian Federation and negative effect is observed at maximum level. It means that medium increase in these indicators leads to economic growth, although rapid growth leads to crises. The devaluation of the ruble, the decline in investment and innovation activity, the decline in global oil prices have a negative impact on economic development.

\section{Discussion and Conclusions}

Studying of the system of leading indicators of the economic crises on the example of the Russian economy reveals the priority of financial indicators change and their impact on the real GDP index $[21,28,45])$. In other words, economic crises are caused by the changes in the financial sector. The results obtained define the following causes of economic crises: the rapid growth of bank and mortgage lending, the devaluation of the ruble and a decrease in gross foreign investment, capital investment and research and development costs, the decline in global oil prices.

The proposed system of indicators reflects the key indicators of the economic crisis identified by References [2,4,19-23]—indicators of the credit market (X1-X3, X7, X14-X15, X17-X19), currency exchange rate $(X 4)$, stock prices $(X 8, X 9)$, gold and foreign exchange reserves $(X 11)$. It is supplemented by fiscal indicators (X5-X6, X13, X16) characterizing the budget deficit, the volume of public debt and payments for its servicing, as well as the indicators of investment activity $(X 12, X 23)$, innovation activity (X20), global oil prices (X24), the dynamics of the country's sovereign credit rating (X10), which are indicated by References $[25,26,48,51]$ but did not find practical application. Thus, the proposed list of indicators allows for a more comprehensive, compared with existing studies, assessment of indicators of economic crises based on world practice of economic crises: the US crisis 1931, 2000-2001, 2007-2009, Latin America 1980, Japan 1980, Mexico 1994, Asia 1997-1998, East Asia 2000. 
Monetary factors $(X 1, X 2, X 4)$ are statistically significant leading indicators of economic change. This confirms the relevance of the monetarist theory of the development of economic crises [2,21,23], although adjusted for investment factor [51]. This characteristic of the oscillator system can be explained by the fact that the financial system of Russia has not developed yet and is characterized by a developing market, mainly due to the insufficient development of stock markets and institutional investors. This significantly complicates the mobilization of internal sources of long money for the Russian economy. This feature of the Russian financial system must be taken into account for the development of financial system strategies for the future, leading indicators determination and crisis prevention. The authors of the present work are trying to take up this challenge and contribute to the literature on early warning about the crisis, focusing on visualization of the economy and determining the potential leading indicators, which are characteristic for the developing markets. It is worth highlighting that gross investment is one of the leading indicators in the national economy. Therefore, unlike the economies of developed countries, the effectiveness of fiscal expansion policy as a response to the economic crisis and its consequences depends on fiscal and balance-of-payments positions. Russian economy is experiencing a decline in fiscal position. Being an oil exporting country, it significantly depends on oil revenues, which are currently declining. Therefore, the reduction of the investment flow into the economy significantly restricts an expansionary fiscal policy. Unlike a developed economy with a fairly strong public finance base, the investment factor will not have the same impact as in emerging market countries. In a developed market, the accounting rate can be an indicative indicator of the economic crisis. The long period of ultra-low rates contributes to the growth of financial vulnerability factors, especially outside the regulated banking sector.

Also, within the framework of this study the presented approach showed that the innovative level of development significantly affects the development of the economy and indicators of innovative development should serve as the basis for an indicative assessment of crisis manifestations in the Russian economy in the current conditions. In addition, it should be noted that with a decrease in the growth rate of innovative development, there is a decrease in the growth rate of the national economy, which is typical for countries with an emerging market. The importance of the innovation factor in the indicative early warning system for Russia is justified not only by the development of the information economy in the world and in the country but rather by the fact that in Russia innovative activity takes predominantly the form of the introduction of already existing innovative products or processes from more developed countries with their subsequent adaptation to the local conditions [29]. This, in turn, gives rise to significant differences in the level of costs in the process of introducing the existing technologies and provokes the complete dependence of the domestic innovation process on external funding, foreign investment in particular. Since the Russian economy is overly dependent on fluctuations in prices for oil, metals and other types of export raw materials $[25,26]$ and is characterized by the instability of the financial system, there are no mechanisms for transforming its own savings into investments. Consequently, at the slightest disproportionate manifestation of economic development, the already modest level of investment in innovative activity is sharply reduced in Russia, which in turn directly affects the level of investment activity.

The implementation of Granger test and neural modeling to determine the most useful leading indicators of all potential ones can be considered as the advantage and novelty of the present study. Although, the authors of the analyzed literature sources either concerned all potential indicators within the model or selected several indicators for evaluation $[2,36]$. The applied methods allowed us to minimize subjective judgment and reflect the compromise between the inclusion of insignificant indicators (in comparison, when all potential indicators are used) and the omission of important variables (when several selected indicators are evaluated). As a result, the researches formed a subset containing the most important leading indicators that should be controlled by the anti-crisis policy of the state. It is worth highlighting, that the identified system of leading indicators of economic crisis is characteristic only for the Russian economy. Thus, the list of oscillators and the possibility of financial expansion to prevent the economic crisis in the country depends on the balance of payments in the 
developing market and fiscal state. Taking Chinese economy as an example, we can see that in the context of the sufficient foreign exchange reserves and a small fiscal deficit, an effective expansionary fiscal policy can be pursued regardless of the dynamics of investment in the economy. However, other countries, especially in Africa, which do not have large reserves or whose balance of payments is unstable, may not be able to admit expansionary fiscal policies. These aspects, as well as the influence of external economic factors that were not considered in this study, formed our further scientific priority.

In the context of the study, time lags of the economy reaction to the change of leading indicators of crisis were obtained. As the study showed, the dynamics of economic development reacts quickly enough to crisis changes in monitor oscillators with a lag of two quarters, to X12 change (gross foreign investment), X23 (capital investment), X20 (research costs) it comprises three quarters. These results weaken the idea common for the previous literature [39], that all early warnings are indicated on the same horizon, usually one or two years. The authors suggest a systematic way to select the horizon for each potential leading indicator. Most of them are macroeconomic and financial variables and some of them reflect structural and fiscal characteristics. According to the research results, forecasting horizons really depend on indicators and fall in the range from two to three quarters. Thus, the system of leading indicators of crisis in the Russian economy can be qualified as early warning indicators.

Based on the updated system of crisis early warning indicators, their negative dynamics can be stated in the last half of $2019[14,58,61]$ before the start of the crisis in the Russian economy in March 2020 due to the COVID-19 pandemic propagation. Also, the negative dynamics of these oscillators in the second half of 2012 [14,58,61] before the onset of the economic crisis in 2013-2016 may be a confirmation of the sensitivity of the country's economic development dynamics to changes in these indicators. However, within the framework of the research, it should be underlined that the Russian economy is currently undergoing a deep recession because of the pandemic, just like the global economy but this is a humanitarian crisis-a crisis of the healthcare system [12]. Concerning the peculiarities of the Russian economic development, it is subject to systemic crises of the economy, covering all spheres and sectors of the country's economy. And this is typical for economies that, even during recovery phases, will develop according to the scenario of intermediate crises and economic recessions. This is not typical for the classic crisis of overproduction $[38,52]$ but rather indicates an investment and innovation crisis, to be more precise, a crisis of reproduction management in a broad sense, leading each time to a sectoral crisis and a crisis of the socio-economic model of the economic operation. Therefore, these features of the Russian economy crisis and their differences from the crises in developed countries and the global economy will be considered in our future studies.

In this context, Russia should actively implement strategies of open innovation and its commercialization to ensure the leveling of crisis manifestations and sustainability $[47,48,69]$. The state should become the main coordinator of open innovation in the country by developing innovative elevators and technological platforms through financial, informational and advisory support for innovative projects at all stages of the innovation cycle. It should create state guarantees and ensure the protection of information within the framework of the innovation process.

Author Contributions: Conceptualization, A.S. (Alexander Semin); Data curation, M.V. (Marina Vasiljeva), M.M. and M.V. (Maria Volkova); Formal analysis, M.M. and M.V. (Maria Volkova); Investigation, N.N.; Methodology, M.V. (Marina Vasiljeva); Resources, M.V. (Marina Vasiljeva) and I.E.; Visualization, A.Z.; Writing一original draft, A.S. (Alexander Sokolov); Writing-review \& editing, N.K. All authors have read and agreed to the published version of the manuscript.

Funding: This research received no external funding.

Conflicts of Interest: The authors declare no conflict of interest.

\section{Appendix A}

Verification results for the dynamics of the Russian real GDP growth for the period from 1995 to the first half of 2020 concerning the presence of structural shifts. 
Table A1. Characteristics of the linear regression model of the time-dependent real GDP growth rate.

\begin{tabular}{ccccc}
\hline Variable & Coefficient & Std. Error & t-Statistic & Prob. \\
\hline X & 0.000339 & $1.73 \times 10^{-5}$ & 19.63723 & 0.0000 \\
C & 1.134868 & 0.000975 & 1163.964 & 0.0000 \\
R-squared & 0.802339 & & & \\
Adjusted & 0.800258 & & & \\
R-squared & 0.004764 & & & \\
S.E. of regression & 0.002156 & & & \\
Sum squared resid & 385.6209 & & & \\
F-statistic & 0.000000 & & & \\
Prob(F-statistic) & & & &
\end{tabular}

Note: Dependent Variable: real GDP growth rate; $X$-Independent Variable—ordinal number of the timeframe; C—a constant term; Method: Least Squares; Included observations: 97.

Table A2. Results of the Chow test for structural shifts in the dynamics of the real GDP growth rate from 1995 to the first half of 2020.

\begin{tabular}{cccc}
\hline \multicolumn{5}{c}{ Chow Breakpoint Test: 53} \\
\hline \multicolumn{4}{c}{ Null Hypothesis: No breaks at specified breakpoints } \\
\hline \multicolumn{4}{c}{ Varying regressors: All equation variables } \\
F-statistic & 0.391300 & Prob. F (2,93) & 0.6773 \\
Log likelihood ratio & 0.812845 & Prob. Chi-Square (2) & 0.6660 \\
Wald Statistic & 0.782600 & Prob. Chi-Square (2) & 0.6762 \\
\hline
\end{tabular}

\section{References}

1. Butorina, O.V.; Pazdnikova, N.P.; Karpovich, Y.V. The study of modern cyclic processes in the economy of the region. Rev. Espac. 2018, 39, 14.

2. Babecký, J.; Havránek, T.; Matějů, J.; Rusnák, M.; Šmídková, K.; Vašíček, B. Leading Indicators of Crisis Incidence. Evidence from Developed Countries. European Central Bank. 2020. Available online: https://www.ecb. europa.eu/pub/pdf/scpwps/ecbwp1486.pdf (accessed on 15 April 2020).

3. Financial University under the Government of the Russian Federation. The Crisis Cannot Be Predicted, But It Can Be Seen In Time. 2019. Available online: http://www.fa.ru/org/dep/findata/News/2019-07-08ivanyuk-interview.aspx (accessed on 11 November 2020).

4. Asteriou, D.; Spanos, K. The relationship between financial development and economic growth during the recent crisis: Evidence from the EU. Financ. Res. Lett. 2019, 28, 238-245. [CrossRef]

5. Simon, J. Ten years of research-What have we learnt since the financial crisis? Econ. Anal. Policy 2019, 64, 152-158. [CrossRef]

6. Cardarelli, R.; Elekdag, S.; Lall, S. Financial stress and economic contractions. J. Financ. Stab. 2011, 7, 78-97. [CrossRef]

7. Rappeport, A.; Smialek, J.I.M.F. Predicts Worst Downturn since the Great Depression. The New York Times. 2020. Available online: https://www.nytimes.com/2020/04/14/us/politics/coronavirus-economy-recessiondepression.html (accessed on 11 November 2020).

8. History.Com. Great Recession. 2017. Available online: https://www.history.com/topics/21st-century/recession (accessed on 11 November 2020).

9. Giles, C. Global Economy to Suffer Worst Blow Since the 1930s, Warns IMF. Financial Times. 2020. Available online: https://www.ft.com/content/e626cc6f-5aa9-4dae-b6a0-175b92aa126d (accessed on 11 November 2020).

10. World Trade Organization. Trade Set to Plunge as COVID-19 Pandemic Upends Global Economy. 2020. Available online: https://www.wto.org/english/news_e/pres20_e/pr855_e.htm (accessed on 11 November 2020).

11. Goodman, D. World Economy Faces \$5 Trillion Hit That's Like Losing Japan. Bloomberg. 2020. Available online: https://www.bloomberg.com/news/articles/2020-04-08/world-economy-faces-5-trillion-hitthat-is-like-losing-japan (accessed on 11 November 2020). 
12. Vasiljeva, M.; Neskorodieva, I.; Ponkratov, V.; Kuznetsov, N.; Ivlev, V.; Ivleva, M.; Maramygin, M.; Zekiy, A. A predictive model for assessing the impact of the COVID-19 pandemic on the economies of some Eastern European countries. J. Open Innov. Technol. Mark. Complex. 2020, 6, 92. [CrossRef]

13. World Bank Group. Russia Economic Report, No. 41, June 2019: Modest Growth—Focus on Informality; World Bank: Washington, DC, USA, 2019.

14. Federal State Statistics Service. 2020. Available online: https://rosstat.gov.ru/ (accessed on 15 April 2020).

15. Kluge, J. Russia's Economy until 2030: Falling Behind. Atlantic Community. 2020. Available online: https://atlantic-community.org/russias-economy-until-2030-falling-behind/ (accessed on 15 April 2020).

16. World Bank Group. Russia Economic Report, No. 43, July 2020: Recession and Growth under the Shadow of a Pandemic; World Bank: Washington, DC, USA, 2020.

17. Organization for Economic Co-Operation and Development. Composite Leading Indicators (CLI). 2019. Available online: https://www.oecd.org/sdd/leading-indicators/composite-leading-indicators-clioecd-september-2019.htm (accessed on 15 April 2020).

18. International Organization of Securities Commissions. Thematic Review on Suitability Requirements with respect to the Distribution of Complex Financial Products. 2019. Available online: https://www.iosco.org/ library/pubdocs/pdf/IOSCOPD638.pdf (accessed on 15 April 2020).

19. Kuznetsova, S.A. The global financial crisis: Fundamental causes and ways to overcome. Fundam. Econ. Manag. Law 2013, 1, 40-45.

20. Vasina, E.V. World financial crises and their types. Bull. MGIMO Univ. 2015, 4, 271-277.

21. Fedorova, E.A.; Fedorov, F.Y.; Koscheeva, E.E. Development of crisis indicators for the Russian financial market. Financ. Credit 2015, 47, 2-12.

22. Čizo, E.; Ignatjeva, S.; Lavrinenko, O. Determinants of financial development of the EU countries in the period 1995-2017. Insights Reg. Dev. 2020, 2, 505-522. [CrossRef]

23. Lee, S.S.; Luk, P. The Asian financial crisis and international reserve accumulation: A robust control approach. J. Econ. Dyn. Control 2018, 90, 284-309. [CrossRef]

24. Choi, E.J.; Choi, J.; Son, H. The long-term effects of labor market entry in a recession: Evidence from the Asian financial crisis. Labour Econ. 2020, 67, 101926. [CrossRef] [PubMed]

25. Balashova, S.; Serletis, A. Oil prices shocks and the Russian economy. J. Econ. Asymmetries 2020, 21. [CrossRef]

26. Su, C.-W.; Qin, M.; Tao, R.; Umar, M. Does oil price really matter for the wage arrears in Russia? Energy 2020, 208, 118350. [CrossRef]

27. Dong, Y.; Li, C. Economic sanction games among the US, the EU and Russia: Payoffs and potential effects. Econ. Model. 2018, 73, 117-128. [CrossRef]

28. Voskoboynikov, I.B. Sources of long run economic growth in Russia before and after the global financial crisis. Russ. J. Econ. 2017, 3, 348-365. [CrossRef]

29. Gershman, M.; Gokhberg, L.; Kuznetsova, T.; Roud, V. Bridging S\&T and innovation in Russia: A historical perspective. Technol. Forecast. Soc. Chang. 2018, 133, 132-140.

30. Haider, A.; Khan, S.U. A Small Open Economy DSGE Model for Pakistan. Munich Personal RePEc Archive. 2020. Available online: https://mpra.ub.uni-muenchen.de/12977/1/MPRA_paper_12977.pdf (accessed on 15 April 2020).

31. Lang, Y.; Yang, Q. Does public infrastructure breed consumption downgrade and overcapacity in China? A DSGE approach on macroeconomic effects. Sustainability 2019, 11, 831. [CrossRef]

32. Grinin, L.; Korotayev, A.; Malkov, S. A Mathematical Model of Juglar Cycles and the Current Global Crisis. In History \& Mathematics: Processes and Models of Global Dynamics; Grinin, L., Herrmann, P., Korotayev, A., Tausch, A., Eds.; Uchitel: Volgograd, Russia, 2010; pp. 138-187.

33. Lucas, R.E. Lectures on Economic Growth; Harvard University Press: Cambridge, MA, USA, 2002.

34. Kydland, F.E.; Prescott, E.C. Time to build and aggregate fluctuations. Econometrica 1982, 50, 1345-1370. [CrossRef]

35. The Sveriges Riksbank Prize in Economic Sciences in Memory of Alfred Nobel 2004. 2004. Available online: https://www.nobelprize.org/prizes/economic-sciences/2004/summary/ (accessed on 15 April 2020).

36. Hawtrey, R.G. Monetary Reconstruction; Longmans: London, UK, 1926.

37. Bordo, M.D.; Meissner, C.M. Fiscal and Financial Crises; National Bureau of Economic Research: Cambridge, MA, USA, 2016.

38. Engle, R.; Ruan, T. Measuring the probability of a financial crisis. Proc. Natl. Acad. Sci. USA 2019, 116, 18341-18346. [CrossRef] 
39. Kaminsky, G.L.; Reinhart, C.M. The twin crises: The causes of banking and balance-of-payments problems. Am. Econ. Rev. 1999, 89, 473-500. [CrossRef]

40. Igan, D.O.; Moussawi, H.; Tieman, A.F.; Zdzienicka, A.; Dell'Ariccia, G.; Mauro, P. The Long Shadow of the Global Financial Crisis: Public Interventions in the Financial Sector; International Monetary Fund, 2020; Available online: https://www.imf.org/en/Publications/WP/Issues/2019/07/30/The-Long-Shadow-of-theGlobal-Financial-Crisis-Public-Interventions-in-the-Financial-Sector-48518 (accessed on 15 April 2020).

41. Carstens, A. Monetary Policy: 10 Years after the Financial Crisis; Bank for International Settlements, 2020. Available online: https://www.bis.org/speeches/sp190905b.pdf (accessed on 15 April 2020).

42. Financial Stability Board. Implementation and Effects of the G20 Financial Regulatory Reforms. 2020. Available online: https://www.fsb.org/wp-content/uploads/P161019.pdf (accessed on 15 April 2020).

43. Center for Macroeconomic Analysis and Short-Term Forecasting. Composite Leading Indicators. Available online: http://www.forecast.ru/SOI.aspx (accessed on 11 November 2020).

44. Analytical Credit Rating Agency. ACRA Financial Stress Index for Russia. Available online: https://www.acraratings.ru/research/index (accessed on 11 November 2020).

45. Ponomarenko, A.; Tatarintsev, S. Incorporating Financial Development Indicators into Early Warning Systems; Bank of Russia: Moscow, Russia, 2020.

46. Ekimova, N. Indicators of early crisis: In search of new approaches. Bull. Ural Fed. Univ. Ser. Econ. Manag. 2017, 16, 985-1002. [CrossRef]

47. Yun, J.; Liu, Z. Micro- and macro-dynamics of open innovation with a Quadruple-Helix model. Sustainability 2019, 11, 3301. [CrossRef]

48. Yun, J.J.; Won, D.; Park, K. Entrepreneurial cyclical dynamics of open innovation. J. Evol. Econ. 2018, 28, 1151-1174. [CrossRef]

49. Tülüce, N.S.; Yurtkur, A.K. Term of strategic entrepreneurship and Schumpeter's creative destruction theory. Procedia Soc. Behav. Sci. 2015, 207, 720-728. [CrossRef]

50. Yun, J.J. How do we conquer the growth limits of capitalism? Schumpeterian dynamics of open innovation. J. Open Innov. Technol. Mark. Complex. 2015, 1, 17. [CrossRef]

51. Hardy, B.; Sever, C. Financial Crises and Innovation; BIS: Basel, Switzerland, 2020.

52. Massaro, M.; Rubens, A.; Bardy, R.; Bagnoli, C. Antecedents to export performance and how Italian and Slovanian SME's innovate during times of crisis. J. East. Eur. Cent. Asian Res. 2017, 4, 22. [CrossRef]

53. Chernis, T.; Cheung, C.; Velasco, G. A three-frequency dynamic factor model for nowcasting Canadian provincial GDP growth. Int. J. Forecast. 2020, 36, 851-872. [CrossRef]

54. Kalimeris, P.; Bithas, K.; Richardson, C.; Nijkamp, P. Hidden linkages between resources and economy: A “Beyond-GDP" approach using alternative welfare indicators. Ecol. Econ. 2020, 169, 106508. [CrossRef]

55. Ellington, M.; Florackis, C.; Milas, C. Liquidity shocks and real GDP growth: Evidence from a Bayesian time-varying parameter VAR. J. Int. Money Financ. 2017, 72, 93-117. [CrossRef]

56. Salgado, C.M.; Azevedo, C.; Proença, H.; Vieira, S.M. Noise versus outliers. In Secondary Analysis of Electronic Health Records; Springer: Cham, Switzerland, 2016; pp. 163-183. [CrossRef]

57. Pek, J.; Wong, O.; Wong, A.C.M. How to address non-normality: A taxonomy of approaches, reviewed, and illustrated. Front. Psychol. 2018, 9, 2104. [CrossRef]

58. Central Bank of the Russian Federation. 2020. Available online: https://www.cbr.ru/statistics/ (accessed on 15 April 2020).

59. Trading View. 2020. Available online: https://ru.tradingview.com/markets/ (accessed on 15 April 2020).

60. Ministry of Finance of the Russian Federation. 2020. Available online: https://minfin.gov.ru/ru (accessed on 15 April 2020).

61. United States Energy Information Administration. Petroleum \& Other Liquids. Available online: https://www.eia. gov/dnav/pet/hist/LeafHandler.ashx?n=PET\&s=RBRTE\&f=M (accessed on 11 November 2020).

62. Mariani, M.C.; Bhuiyan, M.; Tweneboah, O.K.; Beccar-Varela, M.P.; Florescu, I. Analysis of stock market data by using Dynamic Fourier and Wavelets techniques. Phys. A Stat. Mech. Its Appl. 2020, 537, 122785. [CrossRef]

63. Szulczyk, K.R.; Sadique, S. Using cyclical components to improve the forecasts of the stock market and macroeconomic variables. J. Mod. Appl. Stat. Methods 2018, 17, 2-23. [CrossRef]

64. Kai, X.; Xiaoguang, Y. Predicting default rates by capturing critical transitions in the macroeconomic system. Financ. Res. Lett. 2020, 32, 101107. [CrossRef] 
65. Ma, X.; Samaniego, R. The macroeconomic impact of oil earnings uncertainty: New evidence from analyst forecasts. Energy Econ. 2020, 90, 104832. [CrossRef]

66. Tölö, E. Predicting systemic financial crises with recurrent neural networks. J. Financ. Stab. 2020, 49, 100746. [CrossRef]

67. Coffinet, J.; Kien, J.-N. Detection of rare events: A machine learning toolkit with an application to banking crises. J. Financ. Data Sci. 2019, 5, 183-207. [CrossRef]

68. Nápoles, G.; Jastrze bskka, A.; Salgueiro, Y. Pattern classification with Evolving Long-term Cognitive Networks. Inf. Sci. 2020. [CrossRef]

69. Yun, J.J.; Won, D.; Park, K. Dynamics from open innovation to evolutionary change. J. Open Innov. Technol. Mark. Complex. 2016, 2, 7. [CrossRef]

Publisher's Note: MDPI stays neutral with regard to jurisdictional claims in published maps and institutional affiliations.

(C) 2020 by the authors. Licensee MDPI, Basel, Switzerland. This article is an open access article distributed under the terms and conditions of the Creative Commons Attribution (CC BY) license (http://creativecommons.org/licenses/by/4.0/). 